\title{
Modern African Missionaries. A Reassessment of Their Impact in Uganda 189os-1920s
}

\author{
Emma Wild-Wood | ORCID: 0000-0002-6707-8510 \\ Senior Lecturer in African Christianity and African Indigenous Religions, \\ School of Divinity, University of Edinburgh, Edinburgh, UK \\ emma.wildwood@ed.ac.uk
}

\begin{abstract}
Using examples from Anglican missions in the Great Lakes region of Africa this article explores the roles of African Protestant missionaries in the modern era. It argues that many committed African Christians understood themselves to be missionaries and examines the nature of their missionary activity. Those who called themselves missionaries evangelised outside their own ethnic group. They were engaged in regional and transnational developments. The article attends to local and regional historical processes to show how African missionary activities were infused with transnational notions of belonging to a world religion.
\end{abstract}

\section{Keywords}

missionary - African - Uganda - transnational - local

\section{Introduction}

African missionaries are active today throughout the African continent and the world. Some regard the contemporary phenomenon of African missionaries as a new departure connected with the rise of Pentecostalism. This is partly because of the prevalence of attention to the history of Western missionaries in Africa, and partly because the missionary engagement of Africans in the modern history of Protestant and Catholic churches has often been understood as local evangelism. In the 19th and early 2oth centuries, however, Africans considered themselves to be missionaries and were considered by others as such. 
This article provides information and analysis towards a new examination of African agents of Christianity. By highlighting the missionary nature of the roles of African Protestants, the local engagement and motivation of such men and women is placed in transnational scope, as they propagated international and eternal benefits and regional connections. 'Missionary' is the explanatory key to the reform of self and society often called conversion which, today as in the past, African Christians apply to themselves and encourage others to practice. Reviving the title of 'missionary' for African evangelists who travelled beyond their own people shows that African agents were important regional players in the world-wide propagation of Christianity and collaborated across racial and ethnic difference. ${ }^{1}$

From the mid-eighteenth century a small number of protestant African missionaries like Jacobus Capitein (c.1717-1747), Christian Protten (1715-1769), Frederik Svane (1710-1789) and Philip Quaque (1766-1816) worked on the West African Coast. They were closely connected with the Dutch, Danish and British trading interests that became heavily dependent on slaving. However, it was communities of African migrants or local people who were instrumental in the dissemination of Christianity inland in the early and mid-nineteenth century. ${ }^{2}$ The freed slaves from Nova Scotia who developed a Christian settlement in Freetown, Sierra Leone, were joined by re-captive slaves and Maroons from Jamaica. Some of them developed a Christian Krio community which perpetuated a missionary form of Christianity through trade, education, and evangelism throughout West Africa. Many Krio missionaries who worked among the peoples in the hinterland of Sierra Leone and in present-day Nigeria were re-captives who were returning to their home region, or they were children of re-captives. ${ }^{3}$ The most well-known of these missionaries was Samuel Ajayi Crowther (c.1809-1891) who became bishop of the missionary diocese of the Niger. African missionaries - and also Asian, Pacific and Native American missionaries - joined missionary societies that had been founded in

1 Emma Wild-Wood, "The Travels and Translations of Three African Anglican Missionaries, 1890-1930," Journal of Ecclesiastical History, 67/4 (2016), 781-98; Stephen C. Volz, African Teachers on the Colonial Frontier: Tswana Evangelists and their Communities During the Nineteenth Century (New York: Peter Lang, 2011), 32.

2 See Christine Leveco, "Jacobus Capitein: Dutch Calvinist and Black Cosmopolitan," Research in African Literatures, 44/4 (2013), 145-166; Gunvor Simonsen, "Belonging in Africa: Frederik Svane and Christian Protten on the Gold Coast in the Eighteenth Century," Itinerario, 39/1 (2015): 91-115; Edward E. Andrews "Christian Missions and Colonial Empires Reconsidered: A Black Evangelist in West Africa, 1766-1816," Journal of Church and State, $5^{1}$ (2010), 663-91. African Roman Catholic missionaries were evident from the sixteenth century.

3 Jehu Hanciles, Euthanasia of a Mission: African Church Autonomy in a Colonial Context (Westport, Con: 2002), 5-14. 
Europe, like the Church Missionary Society (CMS) or the Wesleyan Methodist Missionary Society.

Crowther and the emerging church in West Africa influenced cMs secretary, Henry Venn (1796-1873). Venn declared that CMS was to work towards its own 'euthanasia' by creating indigenous churches that were self-governing, financially self-supporting, and self-propagating - an ideal that was not always honoured in its observance. ${ }^{4}$ In the 189 os Alfred Tucker (1849-1914), the same Anglican Bishop of Uganda who lobbied for a British Protectorate of Uganda, introduced the 'three-self' principle in his diocese. ${ }^{5}$ European missionaries expected African Christians to be excellent missionaries because they were closer to the cultures in which they worked. In the mid-nineteenth century the title of missionary was commonly conferred because African Christians were employed by a European mission agency to evangelise their own people. Revd Tiyo Soga (1829-1871), for example, was trained and paid a stipend by the Glasgow Missionary Society of the Free Church of Scotland, to be a missionary to his people, the Xhosa, in southern Africa. ${ }^{6}$ In East Africa re-captives and escaped slaves were employed by the CMS and Universities Mission to Central Africa (UMCA) from 1864. Re-captives educated in Bombay volunteered to participate in the missionary endeavour in Kenya and Tanzania from 186 os. $^{7}$ Escaped slaves independently found in Christianity a spiritual ideology that met their need for asserting their freedom and gaining access to education. ${ }^{8}$ African missionaries also began creating their own evangelistic bands and missionary societies and churches, as European missionaries failed

4 Peter Williams, “'Not transplanting': Henry Venn's Strategic Vision," in: Kevin Ward and Brian Stanley (eds), The Church Mission Society and World Christianity, 1799-1999 (Grand Rapids, MI; Eerdmans, 2000), 147-172.

5 Christopher Byaruhanga, Bishop Alfred Robert Tucker and the Establishment of the African Anglican Church, (Nairobi: WordAlive, 2008), 105-123 and 161-168; Brian Stanley, "Afterword: The CMS and the Separation of Anglicanism from 'Englishness"' in: Kevin Ward and Brian Stanley (eds), The Church Mission Society and World Christianity, 1799-1999 (Grand Rapids, MI; Eerdmans, 2000), 349-350.

6 Tolly Bradford, Prophetic Identities: Indigenous Missionaries on British Colonial Frontiers, 1850-1875 (Vancouver: UBC Press, 2012), 73.

7 Colin Reed, Pastors, Partners, and Paternalists: African Church Leaders and Western Missionaries in the Anglican Church in Kenya, 1850-1900 (Leiden: Brill, 1997). Villages of freed slaves were mainly established by Roman Catholic missions, see: Paul Kollman, The Evangelization of Slaves and Catholic Origins in Eastern Africa (Maryknoll, NY: Orbis Books. 2005).

8 See for example, David Maxwell, "Freed Slaves, Missionaries and Respectability: The Expansion of the Christian Frontier from Angola to Belgian Congo," The Journal of African History 54/1 (2013), 79-102; J.D.Y. Peel, Religious Encounter and the Making of the Yoruba (Bloomington, IN; Indiana University Press, 2000), 242-244. 
to permit autonomy. ${ }^{9}$ From the late 19th century some Africans operated independently of mission agencies, organising their own churches and evangelism. The itinerant preaching, healing, and baptising of William Wadé Harris (c.186o-1928) is one well-known example of missionary activity that revived Methodist and Catholic churches and inspired new independent churches in Liberia, Ivory Coast, Sierra Leone, and Ghana. ${ }^{10}$ Mobility and profound Christian conviction were connected in Africa through the itinerant evangelism of African missionaries.

The appellation 'missionary' cannot be reserved solely for those Africans who travelled thousands of miles, who were trained in India or Scotland, who visited Britain, or who were employed by missionary societies. Some nineteenth century Africans were known during their lifetimes as 'missionaries' and used the title of themselves because they followed Christ's command, "Go and make disciples of all nations (ethnos)" (Matt. 28:19). The particular use of 'indigenous evangelist' in academic literature may be appropriate for some actors but hides the aspirations and commitments of many African Christians. ${ }^{11}$ Historically, Africans who preached among ethnic groups other than their own were regarded as missionaries, and regarded themselves as such. ${ }^{12}$ They promoted a Christian cosmopolitanism through their propagation of the gospel which they believed offered them a universal community of belonging that extended far beyond the region in which they lived and worked. Much of this article demonstrates this missionary outlook and motivation by examining in some detail the activities of men and women in the northern Great Lakes area of Africa. First, we examine the scholarship on African missionaries.

\section{$2 \quad$ 'Black Evangelists' in Scholarship}

Scholarship on the history of African Christianity has frequently divided committed propagators of the religion into two groups: white missionaries and

9 Lamin Sanneh, West African Christianity: The Religious Impact (London: C. Hurst \& Company, 1983) 164-176. See also Emmanuel Lijadu and the Evangelist's Mission Band among the Yoruba from 1898, Adrian Deese, "Divinity and the State: Polity, Sovereignty and Kingship in Anglican Eba-Yoruba Apologetics 1830-897," (PhD Thesis, University of Cambridge, 2019), 22-27, 221-26.

10 David A. Shank, Prophet Harris, the 'Black Elijah' of West Africa (Leiden: Brill 1994); see also five articles on William Wadé Harris in the Dictionary of African Christian Biography at https://dacb.org/sort/stories2/\#H.

11 Bradford, Prophetic Identities, 2-3.

12 Ruth Fisher, Twilight Tales of the Black Buganda, (London: Marshall, 1911), 191-192. 
black, or indigenous, evangelists. The title of Richard Gray's significant work, Black Christians White Missionaries (1990) or that of Peggy Brock, Norman Etherington, Gareth Griffiths and Jacqueline van Gent, Indigenous Evangelists and Questions of Authority in the British Empire (2015) exemplify this point. The racial differentiation has been used for a number of important reasons that emerged from a consciousness by scholars of the racist colonial context in which missionary work operated, and by which it was influenced. Nevertheless, this differentiation has its limitations in reflecting the aspirations of some African Protestant Christians. Studies of 'black evangelists' have demonstrated the dependence on indigenous agency for the success of Christian mission. ${ }^{13}$ The term enabled scholars to highlight the superior influence of Africans in the effective spread of Christianity in sub-Saharan Africa. It drew attention to the agency of those who actions are often obscured or sparsely documented in the historical sources. Mission catechists or independent-minded Christians, men or women, laity and clergy all fall within its compass. Deploying the term 'black evangelists' also contributed to an emphasis on indigeneity that argued that, through African men and women, Christianity in Africa adapted to local worldviews and developed syntheses with local religious beliefs and practices. Black evangelists translated the gospel into the thought forms and practices of African peoples, thus ensuring that Christianity became an African religion. In making the distinction between white missionaries and black evangelists, scholars attempted to demonstrate the attraction that Christianity held for many African people. They rebutted assumptions that conversion to Christianity was a product colonial coercion. They drew attention to activities of colonial dissent within independent Christian movements. However, scholars had few categories for comprehending those movements and people for whom the foreign and novel was attractive, or for understanding transnational connectivity and collaboration. They were predisposed to expect change to take place through steady processes and to doubt converts' claims of stark difference between present commitments and their past life. ${ }^{14}$

13 Norman Etherington, "Introduction" in: Missions and Empire (Oxford: Oxford University Press, 2005), 1-18; Patricia Grimshaw and Andrew May, "Reappraisals of Mission History: An Introduction," in: Grimshaw and May (eds), Missionaries, Indigenous Peoples and Cultural Exchange (Brighton: Sussex Academic Press, 2010), 6; Peggy Brock, "New Christians as Evangelists," in: Peggy Brock (ed), Indigenous Peoples and Religious Change (Leiden: Brill, 2005), 132-152.

14 Joel Robbins, "Continuity Thinking and the Problem of Christian Culture: Belief, Time and the Anthropology of Christianity," Current Anthropology, 48/1 (2007), 5-38; Henri P.P. Gooren, Religious Conversion and Disaffiliation: Tracing Patterns of Change in Faith Practices (New York: Palgrave Macmillan, 2010). 
Until recently, some assumed that Africans, whose Christian affiliation appeared to be orthodox, mission-initiated, culturally foreign and politically acquiescent, were little more than stooges of imperial influence, unable to enculturate Christianity. ${ }^{15}$ There was a preference for studying movements that appeared religiously heterodox (by western standards), ecclesiastically independent, culturally African and politically engaged in proto-nationalist resistance. ${ }^{16}$ They overlooked significant elements in historic transmission of Christianity in which Africans were intrigued by the cosmopolitanism that Christianity proposed. In responding to the critique of the modern missionary movement as entangled in imperial perspectives and ambition scholars have failed to explore why the missionary role was adopted by some Africans. There has been modest change in this regard, as illustrated by Tolly Bradford's Prophetic Identities: Indigenous Missionaries on British Colonial Frontiers (2012). The convenience and good intentions of using 'white missionary' and 'black evangelist' has established racial distinction in African historiography that was less apparent in the nomenclature of the time, and which assumes that evangelists were black Africans working locally and missionaries were white westerners working internationally. ${ }^{17}$ It was these distinctions that white and black missionaries believed could be overcome through Christianity. To use theological language, in attending to the incarnational, scholars have neglected the attraction of the transcendent in the spread of Christianity on the African continent. Or, in sociological language, the focus on the local, indigenous adaptation of Christian neglected the attraction of transcontinental, cosmopolitan connectivity.

A transnational turn in scholarship to interconnections across boundaries of state, culture and continent has portrayed the growth of Christianity in Africa as entangled in global histories of social change and cross-cultural collaboration..$^{18}$ Agents of African Christianity were purveyors of a Christian vision of transformed society and united humanity. They demonstrated a local

15 Ado K. Tiberondwa, Missionary Teachers as Agents of Colonialism: A Study of their Activities in Uganda, 1877-1925 (2nd ed. Kampala; Fountain 1998), 123-131.

16 Paul Kollman, "Classifying African Christianities; Past Present and Future," Journal of Religion in Africa 40/1 (2010), 3-32. B. Jules-Rosette, "At the Threshold of the Millennium: Prophetic Movements and Independent Churches in Central and Southern Africa," Archives de Sciences Sociales des Religions 42/99 (1997), 153-167; for an example of attention to inculturation see, Robert Houle, Making African Christianity: Africans Reimagining their Faith in Colonial Africa (Bethlehem, 2011).

17 The usage also hides the involvement of African American and Caribbean missionaries.

18 Joel Cabrita and David Maxwell, "Introduction," in:Joel Cabrita, David Maxwell and Emma Wild-Wood (eds), Relocating World Christianity: Interdisciplinary Studies in Universal and Local Expressions of the Christian Faith (Leiden: Brill, 2017), 1-25. 
engagement with cosmopolitan influences. They spread spiritual knowledge, practices and relationships that have often been understood to be controlled by seemingly more powerful western agents. The modern missionary movement has been re-examined by reading the imperial metropole and the colony as a single analytic field of 'social and political reverberations'. ${ }^{19}$ Missionary activity has been studied as networks of transregional Christian activity, the exchange and production of knowledge, the formation of hybrid identities, the development of international friendships between Africans and European missionaries, and aspirations to form a worldwide Christian culture. ${ }^{20}$ These studies do not resort to a pursuit of African authenticity that regards foreign influence as always obstructive and dominant, and cultural change as emerging only from mutual misunderstanding and distrust. ${ }^{21}$ They provide examples of mutual collaboration in the colonial era that critique the view of the colonization of African consciousness through the imposition of alien beliefs and practices. $^{22}$ They allow an examination of those areas in which the Christian commitment of Europeans and Africans produced overlapping aims and objectives. Studying the role of African agents of Christianity recalibrates a transregional focus from attention to influences of the colony upon the metropole and towards African comprehensions of transregional networks as signs of a wider community. Studying African missionaries shows the nature, manner, and pervasiveness of the exchange of ideas and technologies. It shows a long-term, internal rationale for the appeal of external influence, and the

19 Frederick Cooper and Laura Anne Stoler, "Between Metropole and Colony: Rethinking a Research Agenda," in: Frederick Cooper and Laura Anne Stoler (eds), Tension of Empire, Colonial Cultures in a Bourgeois World (Berkeley: University of California Press, 1997), ${ }^{1-56 .}$

$20 \quad$ Patrick Harries and David Maxwell, "The Spiritual in the Secular," in: Harries and Maxwell (eds), The Spiritual in the Secular, Missionaries and Knowledge about Africa (Grand Rapids, MI; Eerdmans, 2012), 1-2; Sujit Sivasundaram, Nature and the Godly Empire: Science and the Evangelical Mission in the Pacific, 1795-1850 (Cambridge: University of Cambridge Press, 2005); Dana L. Robert, "Cross Cultural Friendship in the Creation of Twentieth-Century World Christianity," International Bulletin of Missionary Research, 35/1 (2012), 100-107; Hilde Hielssen, Inger Marie Okkenhaug, and Karin Hestad Skeie, "Introduction" in: Hilde Hielssen, Inger Marie Okkenhaug, and Karin Hestad Skeie (eds), Protestant Missions and Local Encounters in the Nineteenth and Twentieth Centuries: Unto the Ends of the Earth (Leiden: Brill, 2011), 3 .

21 Nancy Rose Hunt, A Colonial Lexicon of Birth Ritual, Medicalization, and Mobility in the Congo (Durham, NC; Duke University Press, 1999).

22 V.Y. Mudimbe, The Invention of Africa: Gnosis, Philosophy, and the Order of Knowledge (Bloomington, IN; Indiana University Press, 1988), 48, 65-67; Tiberondwa, Missionary Teachers, vii-viii; Jean and John Comaroff, Of Revelation and Revolution, vol. 1 (Chicago: Chicago University Press, 1991), 12, 19-26. 
regional purchase of novel ideas, their adaptation and exchange. Africans worked to extend Christianity territorially because they developed a commitment to its cosmopolitan nature and universal claims. That is, they believed that it offered a worldwide human community with a shared morality. This community offered particular perspectives on relationships with the divine. Christian cosmopolitanism was demonstrated in new technologies, opportunities for travel and new relationships, which served to shift cultural norms in ways they considered compelling. To illustrate these points in some detail we turn now to Africans operating in the Great Lakes region of Africa who were members of the Anglican church.

\section{3}

\section{Uganda}

In Uganda Protestant and Catholic forms of Christianity were spread rapidly by lay and ordained African Christians. Significant numbers of them left their homes to do so. The encounter with Christianity by the Baganda people in the northern Great Lakes region from 1877 is familiar to many mission scholars and Africanists. There was a rapid acceptance of Christian belief and practice in a kingdom which already had an appetite for regional political alliances and territorial expansion. The Baganda had a range of religious beliefs and practices that operated beyond the orbit of close kinship or clan. They also had a complex socio-political system that, by the end of the nineteenth century was under severe stress. ${ }^{23}$

Muteesa, the ruler of Buganda from 1856 until 1884, welcomed international visitors including CMS missionaries and Roman Catholic White Fathers from 1877. They arrived immediately prior to European commercial or political interests and competed with each other and with Muslims for the souls of Africans. Interest in Christianity remained largely the preserve of the court. Some pages were killed because their Christian commitment conflicted with the orders of King Mwanga, Muteesa's son (1885-6). The spread of Christianity was at first an accidental bi-product of displacement into neighbouring kingdoms during the civil wars (1888-1893). Christianity provided an ideology for the reform of society by Baganda political leaders who wished to modernise their kingdom

23 Holly Hanson, Landed Obligation: The Practice of Power in Buganda (Portsmouth: Heineman, 2003); Neil Kodesh, Beyond the Royal Gaze: Clanship and Public Healing in Buganda (Charlottesville, University of Virginia Press, 2010); Richard J. Reid, Political Power in Pre-colonial Buganda: Economy, Society and Warfare in the Nineteenth Century (Oxford: James Currey, 2002). 
and wield influence over neighbouring kingdoms. In 1893 a revivalist movement among Protestant Christians prompted an enthusiasm to spread literacy and preach the gospels which was more than matched by a similar dedication among Catholic catechists. By 1895 significant numbers of Baganda were using trade routes and regional political alliances as means to preach the gospel to neighbouring peoples. These 'native teachers' of Christianity who evangelised beyond their own people were considered by their contemporaries to be missionaries. Kasagama (c.1865-1928), the King of Toro and ally of the Baganda, welcomed Baganda missionaries to his politically fragile kingdom, as he sought to maintain control. ${ }^{24}$

In Black Evangelists (1978) Louise Pirouet charted the geographical spread of Christianity by Baganda evangelists through mission stations and churches. ${ }^{25}$ Pirouet plotted lines of conversion with access to power and concluded that the Baganda missionary advance was coterminous with, but not entirely coequal to, Baganda expansionist ambitions along all its frontiers. The kingdom of Toro, for example, became a sustainable, cohesive political entity only with the arrival of Christianity and colonialism, mediated initially by Baganda missionaries. The Baganda missionaries and the Toro Christian king, Kasagama, introduced a new social order which they believed brought peace and unity to a divided region. As some of our examples below demonstrate, this was not accepted by all the Toro inhabitants. Nevertheless, in the course of a generation, Toro became largely Christian. Baganda and Batoro missionaries also went to the kingdoms of Ankole in the south and Bunyoro in the north, they visited the Ituri rainforest and the western side of Lake Albert (now in DR Congo).

Pirouet's socio-political historical view of the structures and interests in the spread of Christianity identifies African missionaries as intermediaries of new, international, and regional influences who expanded a modern, Ganda influence. Heike Behrend, in Resurrecting Cannibals (2011), applies an anthropological approach to explore the possible internal motives for and against religious change and offers a glimpse of the reaction of the receptors of African missionary's enthusiasm within the cosmologies and moral economies of Toro. Behrend identifies a positive reception of Christianity within a longer tradition of anti-witchcraft cults. ${ }^{26}$ Baganda missionaries who propagated literacy, Bible

24 Emma Wild-Wood, The Mission of Apolo Kivebulaya: Religious Encounter and Social Change in the Great Lakes c.1865-1935 (Woodbridge: James Currey, 2020), 121-123, 135-138.

25 Louise Pirouet, Black Evangelists: The Spread of Christianity in Uganda, 1891-1914 (London: Rex Collins, 1978).

26 Heike Behrend, Resurrecting Cannibals: The Catholic Church, Witch-hunts, and the Production of Pagans in Western Uganda (Woodbridge, James Currey, 2011), 56-8. 
stories and a new ritual worship were understood as combatting witch-activity which was deemed responsible for violence, famine, and disease. The arrival of European missionaries fitted with beliefs surrounding the return of Bacwezi deities, thus reducing the foreignness of Europeans, and making it imperative that they be welcomed and respected. Behrend considers that the Batoro were not interested in personal transformation because that was not the aim of familiar religious practices. However, early Baganda missionaries to Toro were less interested in re-creating the familiar and more concerned with preaching a universal Christian message that was intended to transform the individual and of society and grant access to the global church. Although they worked hard at communicating in terms that could be understood by the peoples they visited, inculturation of the Gospel was not their primary goal. The belief that Christ's death and resurrection offered hope of an equal and cosmopolitan human community, fully realised in heaven, motivated African missionaries.

Baganda missionaries and, soon after, Batoro missionaries travelled between small villages attempting to persuade the inhabitants to listen to their preaching, to learn to read and to build a church. In doing so they called people to a community of belonging beyond their locality by utilizing the novelties and spiritual practices from the wider world. They preached a conversionist message: the transcendent God could be known in Jesus Christ who offered eternal life. The Baganda and Batoro missionaries entered into the trans-historical memory of the biblical texts, playing out the roles of apostles. ${ }^{27}$ They developed a missionary world-consciousness of Christians as a community that encompassed 'all nations.' The transcendent nature of this community was mediated through the peculiarities of imminent and local religious change. Peace and persecution were key ideas that propelled Baganda missionaries to Toro. The first commentary in Luganda on St Matthew's Gospel makes much of these two themes. Written by Ham Mukasa, a chief and prominent member of the Mengo Church Council, in the shadow of the martyrdom of the early Baganda Christians and the civil war, it expresses an expectation that following Christ will bring eventual peace as well as difficulty. The commentary connects their death with martyrs of the patristic age, and the potential suffering of all Christians who spread the Gospel for peace and unity. ${ }^{28}$ Hearers were called to transform themselves and society. It was a startling and radical message intended to open horizons. Change was an avowedly uncomfortable business. Смs missionary Ruth Fisher, who probably knew all four of

\footnotetext{
27 J.D.Y. Peel, Religious Encounter and the Making of the Yoruba (Bloomington, IN; Indiana University Press, 2000), 2, 9.

28 Ham Mukasa, Ekitabo Kitegeza Enjiri ya Matayo (Mengo, CMS, 19oo).
} 
the African missionaries discussed below, said that Christianity 'made heavy and uncompromising demands' on the lives of Africans and 'did not offer any temporal blessings' but rather gave eternal peace and stability. ${ }^{29}$ Establishing a church included forming a moral community with distinctive attributes literacy, monogamy, temperance, the rejection of the power of charms, spirits, and witches. Yet, whilst individuals might feel the stress of change, new technologies - like literacy, cotton, bicycles, and bio-medicine - were deployed as demonstrations of the power of the Almighty and of the wider community of which they could be a part.

\section{Four African Missionaries}

The following four accounts of individual missionaries from the Anglican Church in Uganda - Yasoni Kironde, Apolo Kivebulaya, Andreyea Dwaikaikara and Hana Kagaye - are produced from careful reading of primary sources. Three accounts contain detailed descriptions of local events that took place in villages rarely visited by European missionaries, although all four missionaries worked with CMS colleagues. The stories demonstrate the universal purview of missionaries and their commitment to a belonging that was larger-thanlocal, and which advocated social change. The perspectives and motivations of the missionaries are not sufficiently explained by the political machinations of ruling elites. Nor are they fully elucidated by a focus on internal motivations that assumes a necessary desire by African peoples to protect the local and continue the traditional. The stories include ambivalent and hostile reactions to the missionaries. These reactions do not always represent longer-term trends, but they do allow us to nuance the explanation of outcomes with some knowledge of the substrate of beliefs, practices and social relations in Toro that influenced the adoption and the adaption of Christianity. The stories reveal the rich complexities of religious encounter in particular localities. They also show how African missionaries were attempting to promote a wide vision of human community dependent on a shared worship of a single creator God. These African missionaries used the transfers and interconnections across the boundaries of continent and culture to forge their own identities and refashion society in order that they and others might belong to a wider community.

Yasoni Kironde, a young Muganda teacher who worked in Toro between 1899 and 1901 provided a frank and detailed account of his evangelistic efforts to Baganda church leaders and CMs missionaries at the Mengo Missionary 
Meeting in March 1902. ${ }^{30} \mathrm{He}$ noted the places and dates of his encounters and the numbers of people who attended classes or services. He quoted from John's Gospel and shows the extent to which the tropes of the Gospel had entered his thinking and been applied to his missionary task. He presented himself as a committed and tenacious evangelist, obedient to 'the Lord's will' and determined to bring the 'light' of Jesus into the 'darkness' of people's lives. He was bewildered by the people he encountered in Mwenge district. They frequently ran away from him or chased him from their gardens. His tenacity to teach literacy and a crucicentric gospel in the face of such hostility reveals some objections to his preaching. He was told that he should not bother people whilst there was famine; that Kasagama had taken their children away and they feared Kironde would do the same; that they wanted free books or cloth from a European missionary in exchange for learning to read. One group of people told him their cattle had been bewitched by the Europeans and died. He quotes one retort: "Stop lying to us saying we shall receive eternal life, tell us instead, 'Believe all of you in order that you may die like your cows.' Kironde's message of change was considered to be destructive of life and of community. Literacy, highly prized by young Baganda men like Kironde as a mode of empowerment and engagement in international affairs and a way to access sacred texts, was understood in Mwenge as furthering European interests for which Europeans should pay. At other times Kironde was suspect because he was Muganda. Yet Kironde's account cautions us against the assumption that peoples who shared a common language operated as homogenous unit. In nearby Butanuka where Runyoro-Rutoro was also spoken, women and children were particularly interested in the Sunday services and daily reading classes that Kironde led. Likewise, he reported that the Bamba people on the Semeliki plain were 'very anxious to be taught.' Often ruled by the Batoro, the Bamba did not want to be over-looked if new initiatives were being introduced. Kironde was impatient with the Batoro who viewed his motives as political, and he spoke favourably of those who welcomed new ideas or were curious about learning to read.

Mwenge, the county where Kironde had met significant hostility, had undergone a particularly violent change during the upheaval of the previous decades. An ambivalent relationship between the Batoro and the Baganda stretched into the distant past. Until the 1870 os Mwenge had been a prosperous, semi-independent county of Bunyoro to which the king sent his sons for education and his cattle for safe keeping. Then it was buffeted by cattle and slave raiding by the Baganda, and by battles for Toro's independence from the once mighty Bunyoro kingdom. The county was hit hard by rinderpest that affected 
western Uganda from the 1880s. Depopulated and impoverished, large areas of the county succumbed to famine. In the 189 os Butiti, the county centre, was governed by Batoro leaders who had been influenced by the Ganda court. In 1901 the Baganda and the British were seen to be exerting too much influence on Toro governance and reducing the quasi-independence of Mwenge. There was little incentive for action and good reason for suspicion about the motives of Baganda preachers. Old economic and cultural structures had been eroded but there was little appetite for Kironde's zealous presentation of alternatives. The asymmetries of regional power were most pressing for the Mwenge farmers who criticised Kironde's preaching. For them the narratives of cosmopolitan inclusion spoke of a loss of independence. From 1901, however, attitudes towards Christianity begin to change in Mwenge. Some people began to respond more favourably to another Muganda missionary, Apolo Kivebulaya. ${ }^{31}$

Kivebulaya insisted on instruction in the Runyoro-Rutoro vernacular and not in his own language, Luganda. His arrival in Mwenge with tracts in RunyoroRutoro appears to have been a success. ${ }^{32}$ Missionaries - both African and European - were divided on the extent to which Runyoro-Rutoro should be used in disseminating the Gospel. A united and regional church, argued some, demanded a single language in which to operate. ${ }^{33}$ Kivebulaya is the earliest missionary on record to insist that the Runyoro-Rutoro language was significantly different to that of Luganda, and that the Banyoro and Batoro should have the entire Bible translated into Runyoro-Rutoro. He wrote to the CMS and the Bible Society about it. For Kivebulaya Christian cosmopolitanism did not require a single language. Kivebulaya however, had had his own difficulties in the western-most parts of Toro.

Kivebulaya had volunteered to go to Toro in 1895 soon after his baptism, in conformity with the Great Commission of Matthew 28 to, 'go and preach to all nations, making disciples ...' He kept a diary and wrote occasional letters and reports until he died in $19333^{34}$ In 1896 Kivebulaya was arrested and almost burnt to death in Mboga (later in Congo) by order of its ruler, Tabaro,

$31 \quad$ For a detailed analysis of Kivebulaya's missionary career see Wild-Wood, The Mission of Apolo.

32 Wild-Wood, The Mission of Apolo, 155-57.

33 For an extended discussion on translation see: Emma Wild-Wood, "Bible Translation and the Formation of Corporate Identity in Uganda and Congo 1900-1940," Journal of African History, 58/3 (2017).

34 Most of Kivebulaya's writings can be found in the archives of the Africana Collection of Makerere University Library. They are translated in Emma Wild-Wood with George Mupanga, The Archive of a Ugandan Missionary: Writings by and about Revd Apolo Kivebulaya (1895-1934) (Oxford: British Academy, Oxford University Press, 2021). 
after the death of a reader and woman of the royal household, Miriam Tuguita. Tuguita had tripped upon a spear and Kivebulaya was accused of her murder. CMS missionary accounts give the impression that Kivebulaya was accused of wielding the spear. Kivebulaya knew that the accusations were more widereaching. He was considered a murderer not because he had attacked Tugita, but because her death was considered another sign of the overturn of the social order. The event occurred after two raids on Mboga and the destruction of homes and land. Tuguita's death, in the eyes of Tabaro, was the latest consequence of attending to new teaching and an indication that the teaching was misleading. The efficacy of religious practitioners was measured by the social flourishing of a community - or their ability to call down misfortune. Some saw Kivebulaya's interventions as spoiling their land and rendering people infertile. He was accused of luring women away from their husbands with fine words. Despite his protestations to the contrary, people in Mboga saw evidence to uphold their convictions. Like Kironde, Kivebulaya recorded a mistrust of the Baganda. Generations of slaving and cattle raiding in the Great Lakes area caused suspicion and mistrust.

On the other hand, the women and young boys who had been beaten for their interest in reading, continued to congregate under the guise of collecting firewood. They followed Kivebulaya because they were drawn to the notion of peace among neighbouring ethnic groups, respect for women, and the rejection of slavery and indentured labour. ${ }^{35}$ They would later record the efforts of Kivebulaya to create new kinds of family units which overlooked familiar kinship patterns and ethnic difference. They would claim that he brought peace among forest peoples because they had become part of the worldwide church. ${ }^{36}$ Chief Tabaro eventually decided to invite Kivebulaya back to Mboga. Ten years later Mboga was a thriving mission station. The same cannot be said of next location although the story appears more hopeful.

Andereya Dwakaikara, a young Banyoro teacher influenced by Baganda missionaries, became a missionary himself on the Congo border from 1902. His story was recorded by his grandson. ${ }^{37}$ On becoming a church teacher Dwakaikara was provided with a white robe (kanzu), a chair and a staff. His robe rendered him visually distinct. The chair elevated him to elder-status, and the staff anticipated the long journeys expected of teachers. He was also equipped with a Bible and a hymnbook in Luganda. Dwakaikara travelled with

35 Wild-Wood, The Mission of Apolo, 145-150.

36 Wild-Wood, The Mission of Apolo, 234-235.

37 H.D. Muherya, "The Rev Andreya Dwakaikara," trans. K. Kabadaki, Occasional Research Papers 9/84 (Makerere University, Kampala, Jan 1973). 
Asanasio Bafirahara to the Balega and attempted to interest their ruler Mpigwa in the message that God had sent his son into the world to bring reconciliation between God and humans. The two missionaries found the cautious king consulting the gods about the meaning of their arrival in his lands. The king housed them in a hut dedicated to the deity, to protect them from local people who feared retribution from entering it. In response to Mpigwa's questions, Dwakaikara and Bafirahara explained that the creator God (Nyamuhanga or Ruhanga) resided in heaven and moved in the world as spirit. They related a new cosmology with a single deity and a single set of religious rites to a familiar creator-god. Likewise, their anti-social refusal to drink beer was explained by recourse to familiar prohibitions: beer, they said, was the totem of Christians and so could not be consumed. They also added that 'no drunkard could inherit the kingdom of God.' A new Christian community was connected through the common observation of a food taboo.

Enslaved Nyoro-speakers were the first people to seek out the missionaries. They came by night to learn to read but did not arouse much suspicion because 'slaves were in the habit of visiting people who had much food.' After a few weeks the king agreed that the children in his family might receive instruction, but he worried that his subjects might 'try to behave as if they were kings' if they were taught. Knowledge was to be tested in the royal household first. Whilst the two missionaries were staying with him, Mpigwa, to his consternation, was summoned to the Belgians. Dawkaikara and Bafirahara counselled Mpigwa neither to fight nor flee. They accompanied Mpigwa to the meeting at which he accepted colonial rule because of the Belgians' superior fighting power. The account ends with Mpigwa appreciating Dwakaikara's role in ensuring a peaceful transition to Belgian rule and advising the Balega to learn from the missionaries, whom he calls, 'these people of God.' Whilst some interpretations might consider Dwakaikara as little more than an imperial agent, in this account he is presented as accustomed to white men and following a God who has equipped him avoid the destruction of the Balega and to mediate peaceful political change. The account infers that Mpigwa's earlier consultation of gods resulted in his final acceptance of the teachers.

Before examining the fourth missionary, Kagaye, a number of similarities between the first three missionary stories can be identified. Generational issues appear to play a role: the three were all men and were all relatively young and single when they embarked on their travels. They emphasised their relationship with God and other Christians beyond the bonds of family and society. The single state of the young men maintained their position as mobile oddities in societies with a high regard for kin and fertility. Youth and societal detachment may have increased mobility and a commitment to evangelism 
and church planting. The arrival of Christianity appears to have initially challenged male, gerontocratic power bases in Mwenge and Mboga. Married men were initially ambivalent about engagement with literacy, whereas women and children often responded positively to the teachers, a trend Kironde records with dismay. Slaving practices may well have left ordinary women particularly vulnerable to the whims of their male relatives and eager for alternatives. Among the Balega of the third story, it was hungry male slaves that were first interested in teaching, although their common language and kinship with the missionaries may have attracted them as much as their need for food. The heralding of a new social order through innovations of dress and literacy may also have intrigued listeners.

Kironde, Kivebulaya and Dwakaikara presented a disconnection between spiritual observance and practical, human flourishing. The missionaries gauged their success or failure not in terms of human alliances but in terms of access to divine power. Kironde echoes Fisher's statement (above) in his criticism that the Batoro, 'thought a great deal more about the things they possessed than of religion'. In presenting his report he attributes his lack of success to the hostile Batoro. ${ }^{38}$ He presented something to them which was alien and alienating. Kivebulaya and Dwakaikara were more sympathetic to the dilemmas faced by those who found their missionary ways unsettling. Kivebulaya tended to blame himself for the negative reception he received. All three considered that Christian faith was distinct from material signs of well-being or status and yet they all used technologies to demonstrate spiritual power. Their criteria for successful religious belief and practice, for connection with the supernatural, had significantly shifted from the expectations of those they sought to persuade - something often observed in encounters between European missionaries and Africans. Despite an implicit challenge to authority, the young missionaries hoped to convince chiefs and their courts. Where Christianity took a quick hold, rulers often had an uncertain grip on power, were interested in bringing change, and sought a new moral economy for their societies. The Toro kingdom was not a stable, cohesive polity. It contained areas of waxing and waning support for Kasagama's rule which impacted reception of the religious practices he promoted. The leadership of Tabaro and Mpigwa was buffeted by colonial forces beyond their control. Concerns about social well-being influenced the religious encounter, especially the expectation that good religious-practitioners would ameliorate communal life. When chiefs

38 Yasoni Kironde, “A Muganda Teacher's Story," Uganda Notes (April 1902), 27-29. 
were convinced, men quickly enrolled in literacy classes, and more men were baptised than women. ${ }^{39}$

Hana Kagaye, a prominent Batoro missionary to the Ankole and to her own people, does not conform to the model of the single young men studied above. Kagaye was a mature, married woman when she became a Christian. She was a prominent member of Kasagama's court, whose social responsibilities and status was only below that of the Queen Mother and the King's Sister. It is probable that she held this position because of her spiritual expertise. Prior to her Christian conversion Kagaye was a royal medium, expected to advise the King through a process of spiritual possession. After her conversion, she exerted at least as much influence as a Christian evangelist and missionary to Ankole as she had done as a royal medium. With the Queen Mother, Kahinju, and Queen Damali, Kagaye promoted the Christian education of a generation of Batoro women, and worked closely with Ruth Fisher, Edith Pike and Annie Allen of the CMs. The number of women who trained as teachers was fewer than men, and women who became missionaries beyond their own people were even fewer. Nevertheless, there was a significant minority of women who became teachers and missionaries to neighbouring kingdoms, but there are few accounts of their work. We do not have her own words, but Kagaye's missionary work can be pieced together from a variety of sources. ${ }^{40}$ Kagaye went to Ankole in 1902 with a small group of other Batoro missionaries. She had previously taken refuge in Ankole when Bunyoro had almost re-taken Toro and so knew the people and customs. Her missionary role to Ankole was also an ambassadorial one. She went to royal allies near Mbarara, intent in preaching to their wives and daughters who usually lived in seclusion. As a Christian convert, she accepted a re-ordering of her personal life and preached the same to others: there is no evidence that she attempted to connect the beliefs and practices of her role as a medium with her Christian missionary work. However, she maintained her prominent status by travelling with a large retinue; and first as medium and then as missionary she maintained a dominant role in the sociospiritual affairs.

Kagaye provides a link between the African missionaries described above and the way in which Christian rulers interpreted the message they brought. In

39 W.E. Owen, "Toro Statistics," Uganda Notes, $13 \cdot 7$ (July 1912), 118-9.

40 Elizabeth Dimock, Women, Mission and Church in Uganda: Ethnographic Encounters in an Age of Imperialism, 1895-196os (Abingdon, Routledge, 2017), 91, 94, 105, 114-118. See also various Extracts of the Annual letters of CMS missionaries (CMS, London, 1900-1910). Louise Pirouet, Black Evangelists, 53, 61, 73, 123, 125, 136. 
1908 Kagaye, Kahinju, and Kasagama participated in the revival of a traditional Nyoro royal custom that displayed the king's majesty and his subjects' fealty. On the anniversary of his baptism King David Kasagama reintroduced the crowning ceremony and imbued it with Christian symbolism. ${ }^{41}$ In doing so he reconstructed the corporate memory with elements of old and new in order to reinvent a tradition for a united Toro kingdom. It is from this kind of political project that the deliberate inculturation of Christianity first arose. Meanwhile, many missionaries would continue to preach a religion that attempted to cross ethnic divides rather than one that bolstered ethnic pride.

The stories of these missionaries demonstrate that religious encounter was a complex multi-level phenomenon which potentially involved all aspects of human life. Those committed to evangelism encouraged significant social change that included a cosmopolitan outlook, but their propagation was successful in so far as it negotiated lines of communication and continuity. They exhibited a commitment to evangelise beyond their own people - this is what earned them the title 'missionary' in their own time. Their missionary persona was also created in their belief in a common human community that included all who believed in one God, revealed in Jesus Christ. African missionaries believed that this brought different peoples together and reached across divides of ethnicity, gender, and race. Relationships with Europeans became a significant marker of the common humanity they espoused in Christianity. The four missionaries all worked with European missionaries and formed friendships during preaching safaris, in translation teams, through reporting on their missionary endeavours and through correspondence. They were perceived to have influence with Europeans, possessing the skills and experience to negotiate with them. Good relationships between Africans and Europeans heralded an expectation of a more integrated international society, although the expectation remained unrealized in the imperial age.

In Toro this message seems to have been attractive to indentured labourers, women, young, attached men and people who wielded significant political power. It was less appealing to male householders and rulers who already felt buffeted by change and were suspicious of alliances that might diminish their authority. As a result, regional socio-political relations were significant in shaping reception, even whilst missionaries set their sights on a cosmopolitan and eternal vision.

41 G.R. Blackledge, "The King of Toro's Baptismal Anniversary," Uganda Notes IX, no. 5 (May 1908), 72; Pirouet, Black Evangelists, 69-70. 
African missionaries were not simply 'local' actors. They self-consciously allied themselves with a worldwide movement and they operated on a regional stage. They cast their identity beyond the local. They attempted to persuade others of the attraction of a transnational community which they believed was offered to them in Christianity. Like their European counterparts, they were compelled to leave home and settle in new areas by a desire to preach and plant churches. African missionaries used the interconnections across the boundaries of language and culture to forge their own identities and refashion society so that they and others might belong to a wider community. The transcendent nature of this community was always mediated through the peculiarities of the imminent and local. There is still considerable research to be undertaken to comprehend the historical missionary work of Africans, particularly when they were operating in locations beyond European missionary purview. A painstaking triangulation of sources is required: sources by Africans are scarce, scattered and often brief; the reading of missionary and colonial sources requires careful attention in order to perceive shared interests beyond their inherent biases; and anthropological sources have historically shied away from points of religious encounter.

The four African missionaries studied in this article navigated continuity and change, the indigenous and the foreign, believing themselves to be transformed by their Christian conversion and promoting this transformation to others. Not all converts would made equally radical adjustments to their life. African missionaries navigated the disciplined work of remaking themselves with the equally demanding relational work of creating communities of disciples within a universal church. For African missionaries Christianity was a global force that engendered change on translocal levels. Contemporary African missionaries stand in an eminent tradition of those who have preached - with different levels of success and sensitivity - across geographical, ethnic, and racial boundaries. 